Pushpanathan A., \& Swarnika K.L., Wayamba Journal of Management $12(1)$

\title{
Microfinance Services and Performance of Micro Entrepreneurs: A Study of Pilimathalawa Area
}

\author{
A. Pushpanathan ${ }^{1}$ \& K.L. Swarnika ${ }^{2}$ \\ ${ }^{1,2}$ Department of Economics and Management \\ Vavuniya Campus of the University of Jaffna \\ SRI LANKA \\ a.pushpanathan@vau.jfn.ac.lk ${ }^{1}, \underline{\text { loshisloshi07@gmail.com }}{ }^{2}$
}

\begin{abstract}
Microfinance has evolved as an economic development approach and intended to benefit low-income women and men. The term refers to the provision of financial services to low-income clients, including the selfemployed. Financial services generally include savings and credit; however, some microfinance organizations also provide insurance and payment services. This study examines the influence of microfinance services on the performance of micro entrepreneurs in Pilimathalawa area. 100 micro entrepreneurs who received the benefits from the Samurdhi Bank were selected as sample in this study purpose. The microfinance services micro-credit, micro-savings, and micro-training were considered as independent variables and the entrepreneurs' performance was considered as dependent variables of the study. Data were collected through issuing structured questionnaire to the respondents and analyzed using SPSS version 20. The Correlation analysis, Regression analysis and factor analysis were done to influence of financial services on performance of micro entrepreneurs. The results of the present study indicated that the microfinance services had the significant positive relationship with the entrepreneurs' performance and the microfinance services - micro-credit, micro-saving, and micro-finance have highly impact on the performance of entrepreneurs. Finally, the microfinance services - credits, saving, and training - had highly effect on the performance of the micro entrepreneurs. Further, the study revealed that the micro-savings has most important to the micro entrepreneurs in the Pilimathalawa area in Sri Lanka
\end{abstract}

Keywords:- Micro Entrepreneurs, Microfinance Services, Performance 


\section{INTRODUCTION}

Microfinance has evolved as an economic development approach to intend to benefit low-income women and men. The term refers to the provision of financial services to low-income clients, including the self-employed. Financial services generally include savings and credit. However, some microfinance organizations also provide insurance and payment services. In addition to the financial intermediation, many MFIs provide social intermediation services such as group formation, development of self-confidence, and training in financial literacy and management capabilities among members of a group. (Microfinance Handbook, Joanna Ledgerwood). MFIs can be nongovernmental organizations (NGOs), savings and loan cooperatives, credit unions, government banks, commercial banks, or nonbank financial institutions. Microfinance clients are typically self-employed, lowincome entrepreneurs in both urban and rural areas. (Microfinance Handbook, Joanna Ledgerwood). Microfinance has gained recognition as a means of facilitating sustainable economic development in poor countries, and has become a buzzword in international donor circles (Senanayake \& Premaratne, 2005). Hence, it has opened the avenues for obtaining international financial capital (Khavul, 2010).
Entrepreneurs are very crucial to the development of a country's economy, especially countries like Sri Lanka. Services of Microfinance Institutions encompass financial services such as provision of loans, offering facilities for savings, insurance policies and payments services among many others, as well as social intermediation services such as group formation, development of self-confidence, and training in financial literacy and management capabilities among members of a group. These services are offered to lower income clients including self-employed entrepreneurs with the object of supporting for their performance

Today the area wise institutions provide microfinance in Sri Lanka, such as state banks, Regional Development Banks and other licensed specialized banks, Co-operative rural banks and other co-operatives, Thrift and credit cooperative societies (TCCSs/Sanasa Societies), Samurdhi Bank Society, NGOMFIs and Other financial (Micro finance industry report, 2009). The research question of the present study is; how do the microfinance services influence the performance of the micro entrepreneurs?

Most of the small scale entrepreneurs in Pilimathalawa area are attached with the 
microfinance organizations to get microfinance services, and their performance also may vary from entrepreneur to entrepreneur. Therefore present study investigates the influence of microfinance services in entrepreneurs' performance. Hence the objectives of the present study are to;

- Measure the relationship between services of microfinance institutions and entrepreneurs' performance.

- Measure the impact of microfinance services on the performance of the micro entrepreneurs.

- Rank the most important factor of microfinance services providing by the Samurdhi Bank.

\section{LITERATURE REVIEW}

Today there are varieties of institutions provide microfinance in Sri Lanka, such as state banks, Regional Development Banks and other licensed specialized banks, Co-operative rural banks and other co-operatives, Thrift and credit cooperative societies (TCCSs/Sanasa societies), Samurdhi bank society, NGOMFIs and Other financial institutions (this category includes commercial banks, registered finance companies \& etc. which offer some microfinance services.) (Micro finance industry report, 2009)

An entrepreneur is someone who develops a business model, acquires the necessary physical and human capital to start a new venture, and operationalizes it and is responsible for its success or failure. Entrepreneurs play a major role in Sri Lankan's economic development. But entrepreneurs in Sri Lanka are facing greater challenge in the modern business environment under tough competition, rapidly changing new technologies, globalization of products and services and investment issues.

The microfinance banks services have significantly improved the performance of women-owned enterprises in Benue State, Nigeria. The study concludes that microfinance banks loan services and saving services have more significant effect on the performance of women-owned enterprises. The study also concludes that training services offered by microfinance banks have significantly improved the skills and experiences of women which are transferred to their enterprises (Diaka \& Asenge 2019). Haider et. al., (2018) highlighted training of microfinance beneficiaries is vital for getting better performance. The results indicated that the growth rate of Micro and Small enterprises whose owners had been trained were better as compared to those Micro and small enterprises whose owners had never been given training.

Kingsley Bernard et. al. (2017) discussed the influence of microfinance services on 
entrepreneurial success of women in Sri Lanka. Micro-credit, micro-savings, and microinsurance were considered as an independent variables and entrepreneurial success of women was considered as dependent variables of this study. Further the study found that the positive relationship among micro-credit, and micro-savings and entrepreneurial success of women and the negative relationship between micro-insurance and entrepreneurial success. Khin et.al. (2017) found that the significant microfinance service factors influencing on entrepreneurial success of women entrepreneurs utilizing such services in Sri Lanka.

Herath et. al. (2015) found that the impact of microfinance on poverty and vulnerability of women borrowers. The finding of this study identified that four criteria - access, creation and control over private resources, freedom of decision making at home, self-confidence on socio economic activities and status in community and family were positively affected the women. A qualitative study expressed that the influence of microfinance services (micro-credit, microsavings, micro-insurance, Business support, skills development) on entrepreneurial success of poor women. Further the study discussed weaknesses of such services in the process of women achieving entrepreneurial success (Kingsley Bernard 2015).
In Sri Lanka the small entrepreneurs of rural area are an important unit contributing to the economic growth of the country and microfinance programs were directly relate new small entrepreneurs in the main sectors of agriculture, manufacturing and service sectors. As microfinance service micro-credit is an important tool for some households which already engaged in entrepreneurship and it allows expansion of the household business for those with high returns. As well as social mobilization and training activities played important roles bringing about community involvement and people empowerment. (Prasansha Kumari, 2014)

The changes in the performance of small and medium enterprises experienced after contracting micro-loans and other services were increased brand awareness as the highest area of performance change, followed by an increase in productivity, increased facilities for operations and an increased customer base. And also Changes experienced by the entrepreneurs as individuals after contracting micro-loans and other services was indicated as an increase in management skills, followed by becoming a role model and an increase in personal income. The provision of a micro-loan by micro-finance institutions was rated as the highest factor that positively contributed to the performance of 
small and medium enterprises, followed by the general performance of the economy and consulting services. Finally Provision of micro-loans by micro-finance institutions was rated as the factor that positively contributed to the performance of small and medium enterprises (Kinimi 2014)

The research study of Kithae (2013) derived microfinance factors named; credit, savings, social capital, opportunity and attitude to risk are all positively related to women entrepreneurs' performance in Kenya. As well as opportunity for entrepreneurial activity mediates the relationship between credit, savings, training and social capital and women entrepreneurs' performance and attitude to risk moderates the relationship between above four variables and women entrepreneurs' performance. And both opportunity and attitude to risk are positively related with the women entrepreneurs' performance. Further, Osunde (2012) and Ojo Olu (2009) shows that the microfinance institutions are evident tools for entrepreneurship development due to the various services they offer and the role they perform towards the development of the economy.

Entrepreneur orientation was depending on owner/managers innovativeness. Those owners /mangers that possess creative ability, adequate technical skills and industry experience were supported to be innovative. Availability of financial capital was important to introduce new innovations, capture efficient technology and expand domestic and export market. Most small and medium enterprises in Hambanthota district were lacking awareness of alternative source of finance. Therefore, this study highlighted, government and non-government sector to focus on promoting the level of entrepreneur's orientation performance by directing research and development activities, providing financial resources, training package and consulting services Fairoz et. al., (2010).

Even though many of the foreign and Sri Lankan researchers conducted the research regarding impact of micro finance in entrepreneurial development and women entrepreneurs' performance and also there were a few numbers of researchers discussed that the effects of microfinance factors on entrepreneurs' performance in Sri Lanka. These studies also based on the entrepreneurs' performance. Therefore, researchers have identified this as the research gap and going to carefully investigate the effect of microfinance in entrepreneurs' performance.

Microfinance generally refers to the provision of basic financial services such as loans, saving 
accounts and insurances for lowincome people but economically active people. In most instances the term microfinance refers to the provision of small loans (micro credits) for microentrepreneurs. Three microfinance services were taken to this study purpose such as microcredit, micro-savings, and micro-training. These are considered as independent variables and perceived performance was considered as dependent variable in the present study.

Based on the above literature survey, following hypotheses were derived in this study.

$\mathrm{H}_{1}$ : There is a relationship between Microfinance services and entrepreneurs' performance.

$\mathrm{H}_{2}$ : Microfinance services have higher impact on the entrepreneurs' performance

\section{METHODOLOGY}

\subsection{Sample of the Study}

The target participants for this study were micro entrepreneurs (owners of micro enterprises). The micro entrepreneurs were selected from those who received microfinance services from Samurdhi Bank in Pilimathalawa area. In total, hundred (100) entrepreneurs who made use of micro finance services from selected Samurdhi Bank institution. Simple random sampling technique was used to select from the target population in Samurdhi beneficiaries in Pilimathalawa area.

\subsection{Data Collection}

For this study purpose, closedended questionnaires were prepared to collect the primary data. The final questionnaire consisted of three sections as A, $\mathrm{B}$, and $\mathrm{C}$. The section A consists of demographic profile of the respondents like gender, age, education level, marital status, and experience in business and business type. The section B consists of functioning of microfinance institutions and section $\mathrm{C}$ consists of the microfinance services and entrepreneurs' performance related information. The questionnaire issued to micro entrepreneurs and 100 entrepreneurs perfectly filled and returned the questionnaires to the researchers.

\subsection{Data Analysis}

The collected data were entered and analyzed using SPSS version 20. Correlation analysis - This technique is used to find out the relationship among the variables, Multiple Regression analysis - It generally explains the relationship between multiple independent variables and one dependent variable. It is a statistical tool used to determine the probable change in one variable for the given amount of another variable and factor 
analysis were done for ranking the microfinance services to the micro entrepreneurs. Reliability and validity of the data were examined in this study for measuring the adequacy of the data.

\section{RESULTS AND DISCUSSIONS}

\subsection{Reliabilty Test}

Before analysing the variables in detail and testing the hypothesis, a reliability test was done by the researchers to examine whether the data available is fit for analysis or not. Reliability test is of paramount importance, since it identifies whether the questionnaire and the data collected through distributing the questionnaires are reliable. Therefore, to fulfil the requirement of the reliability in this study, the Cronbach's alpha model was used to test the reliability of the variables used in the study. The Cronbach's Alpha value of the variables is 0.977 . It indicates that the instrument developed in the research had been designed with a higher level of reliability and internal consistency. The results of the study were illustrated in the Table 1.

\begin{tabular}{|c|c|}
\hline \multicolumn{2}{|c|}{ Table 1: Reliability Statistics } \\
\hline $\begin{array}{c}\text { Cronbach's } \\
\text { Alpha }\end{array}$ & No of Items \\
\hline .977 & 20 \\
\hline \multicolumn{2}{|l|}{ Source: Survey data } \\
\hline
\end{tabular}

\subsection{Validity Test}

For this study purpose, the KMOBartlett Sphericity Test (Kaiser Meyer - Olkin and Bartlett's Test of Sphericity) was examined to test the validity of the research and the research instrument.

The KMO (Kaiser - Meyer Olkin) measures the sampling validity. The value of Kaiser Meyer - Olkin measure of sampling adequacy should be greater than 0.5 for a satisfactory level.The measure can be interpreted as meritorious if it carries a value of 0.80 or above. Higher the value indicates higher the validity of the research instrument. The score of KMO Bartlett is 0.841 , which is in the range of "Meritorious" and supports this study in terms of validity. Moreover, according to the Bartlett's Test of Sphericity the $\mathrm{P}$ value is 0.000 , which is also good enough to reject the null hypothesis and accept the alternative hypothesis since the $\mathrm{P}$ value should be 0.05 as per the rule of thumb. The results were illustrated in the Table 2.

\begin{tabular}{|l|l|r|}
\hline \multicolumn{3}{|c|}{ Table 2: KMO and Bartlett's Test } \\
\hline $\begin{array}{l}\text { Kaiser-Meyer-Olkin Measure } \\
\text { of Sampling Adequacy. }\end{array}$ & .841 \\
\hline $\begin{array}{l}\text { Bartlett's } \\
\text { Test of } \\
\text { Sphericity }\end{array}$ & $\begin{array}{l}\text { Approx. Chi- } \\
\text { Square }\end{array}$ & 2718.105 \\
\cline { 2 - 3 } & df & 91 \\
\cline { 2 - 3 } & Sig. & .000 \\
\hline \multicolumn{2}{|l|}{ Source: Survey Data } \\
\hline
\end{tabular}




\subsection{Testing of Hypotheses}

\section{Relationship between \\ Microfinance services and entrepreneurs' performance}

For testing the $\mathrm{H}_{1}$ : There is a significant relationship between Microfinance services and entrepreneurs' performance the researchers done the correlation analysis. The correlation between microfinance credit service and entrepreneurs' performance is 0.870 and the significant value $(\mathrm{p}$ value) is 0.000 under 0.01 significant levels. According to the correlation value microfinance credit and entrepreneurs' performance are positively correlated. The correlation between microsavings service and entrepreneurs' performance is 0.696 and the significant value $(\mathrm{p}$ value) is 0.000 under 0.01 significant levels. Hence the results observed that the positive relationship between Microfinance savings and entrepreneurs' performance has positive relationship in this study. The correlation between microfinance training service and entrepreneurs' performance is 0.709 . And the significant value (p value) is 0.000 . Therefore, the correlation value microfinance training and entrepreneurs' performance are positively correlated. The results of the study are illustrated in the Table 3.

\begin{tabular}{|l|l|l|}
\hline \multicolumn{3}{|c|}{ Table 3: Results of correlation among } \\
variables \\
\hline Variable & $\begin{array}{l}\text { E- } \\
\text { performance }\end{array}$ & $\begin{array}{l}\text { Sig.(2- } \\
\text { tailed) }\end{array}$ \\
\hline M-credit & $0.870^{* *}$ & 0.000 \\
\hline M-saving & $0.696^{* *}$ & 0.000 \\
\hline M-training & $0.709^{* *}$ & 0.000 \\
\hline $\begin{array}{l}\text { Note: ** represents correlation is } \\
\text { significant at level 1\% }\end{array}$ \\
\hline \multicolumn{2}{|c|}{ Source: Survey data } \\
\hline
\end{tabular}

Finally, the study found that the relationship between microfinance services and entrepreneurs' performance has a significant positive relationship. Hence the hypothesis 1- There is a significant relationship between Microfinance services and entrepreneurs' performance is supported.

\section{Impact of Microfinance services on the Performance of Entrepreneurs.}

For testing the Hypothesis 2, the Microfinance services have higher impact on the entrepreneurs' performance e regression analysis was done in this study. The results are illustrated in the Table 4, and Table 5 .

Table 4: Results of model fit

\begin{tabular}{|l|l|l|l|l|}
\hline Model & $\mathbf{R}$ & $\mathbf{R}^{2}$ & $\begin{array}{l}\text { Adjusted } \\
\mathbf{R}^{2}\end{array}$ & $\begin{array}{l}\text { Sig- } \\
\text { value }\end{array}$ \\
\hline 1 & 0.902 & 0.813 & 0.807 & 0.000 \\
\hline \multicolumn{4}{|c|}{ Source: Survey Data } \\
\hline
\end{tabular}

The results from Table 4 shows that coefficient of determination (R-square) explains the variation 
in the dependent variable due to changes in the independent variable. The $\mathrm{R}$-square value of 0.813 is an indication that there was variation of $81.3 \%$ in performance of entrepreneurs. Due to the changes in microfinance credit service, microfinance savings service and microfinance training service of 95\% confidence interval. Also the value of $R$ (0.902) indicated that there was strong relationship between variables. As well as statistics in table 5 indicates, that which is the population's parameter had a significance level of 0.000 which shows that the data is ideal for making conclusion in the population's parameter as the value of significance (P-value) is less than $1 \%$. This implies that microfinance credit service, microfinance saving service and microfinance training service significantly affect the performance of entrepreneurs in Pilimathalwa area.

\begin{tabular}{|l|l|l|l|l|}
\hline \multicolumn{5}{|c|}{ Table 5: Estimated results of multiple Regression } \\
\hline Variables & $\begin{array}{l}\text { Unstandardized } \\
\text { coefficients }\end{array}$ & Std.Error & $\begin{array}{l}\text { Standardized } \\
\text { coefficients }\end{array}$ & Sig.value \\
\hline Constant & 0.751 & 0.152 & & 0.000 \\
\hline M-credit**** & 0.548 & 0.067 & 0.579 & 0.000 \\
\hline M-saving*** & 0.166 & 0.055 & 0.183 & 0.003 \\
\hline M-training*** & 0.213 & 0.048 & 0.256 & 0.000 \\
\hline Note: **** represents 1\% level of significant \\
\hline Source: Survey Data \\
\hline
\end{tabular}

In the above table, Firstly, regression coefficient for microfinance credit service is 0.548 , which implies that, the respondent who have strongly agreed and more satisfied with the micro-credit service given the microfinance institutions, their performance also will be higher.

In other words, the entrepreneurs have better micro credit services, their performance also higher. Based on the study P-value for microfinance credit service 0.000 is less than 0.01 which is an indication that variable has a positive significant effect on the performance of entrepreneurs.

Secondly, the regression coefficient for microfinance saving service is 0.166 , which implies that, the respondent who has strongly agreed and more satisfied with the micro-saving service given by the microfinance institutions, their performance also will be higher. Based on the study P-value for microfinance savings service 0.003 is less than 


\section{Pushpanathan A., \& Swarnika K.L., Wayamba Journal of \\ Management 12 (1)}

0.01 which is an indication that variable has a positive significant effect on the performance of entrepreneurs.

Finally, microfinance training service is 0.213 , which implies that, the respondent who has strongly agreed and more satisfied with the micro-training service given by the microfinance institutions, their performance also will be higher. In other words, as the entrepreneurs have better micro-training services in their performance. According to the study P-value for microfinance training service 0.000 is less than 0.01 which is an indication that variable has a positive significant effect on the performance of entrepreneurs.

Based on the regression results the hypothesis 2 is supported in this study. Hence these three services highly impact on the performance of the entrepreneurs in Pilimathalawa area.

For ranking the microfinance services, an exploratory factor analysis with Varimax rotation was measured. 14 items of the microfinance services, and three components with eigen value greater than 1.00 were extracted with the total variance $88.86 \%$. The rotated factor matrix is illustrated in the Table 6 . The Table 6 shows the variables used for the study purpose which is explained below.
Table 6: Factor loadings and Communality Estimates

\begin{tabular}{|l|l|l|l|l|}
\hline \multicolumn{1}{|c|}{ Item } & \multicolumn{1}{c|}{ F1 } & \multicolumn{1}{c|}{$\mathbf{F 2}$} & \multicolumn{1}{c|}{$\mathbf{F 3}$} & \multicolumn{1}{c|}{$\mathbf{h}^{\mathbf{2}}$} \\
\hline TQ1 & 0.975 & & & 0.629 \\
\hline TQ2 & 0.963 & & & 0.786 \\
\hline TQ3 & 0.969 & & & 0.720 \\
\hline TQ4 & 0.958 & & & 0.780 \\
\hline TQ5 & 0.976 & & & 0.749 \\
\hline SQ1 & & 0.951 & & 0.972 \\
\hline SQ2 & & 0.951 & & 0.973 \\
\hline SQ3 & & 0.956 & & 0.987 \\
\hline SQ4 & & 0.956 & & 0.959 \\
\hline CQ1 & & & 0.788 & 0.992 \\
\hline CQ2 & & & 0.881 & 0.967 \\
\hline CQ3 & & & 0.820 & 0.983 \\
\hline CQ4 & & & 0.860 & 0.957 \\
\hline CQ5 & & & 0.851 & 0.990 \\
\hline Eigen & 6.67 & 3.37 & 2.40 & \\
\hline Variance & 47.63 & 24.07 & 17.16 & \\
\hline Com.Var & 47.63 & 71.69 & 88.86 & \\
\hline Source: Survey & & \\
\hline
\end{tabular}

Source: Survey data, $\mathrm{h}^{2}=$

Communality Estimates

The Three factors grouping can be used to represent the data. The factors are micro-training, microsavings, and micro-credit.

\section{Factor I: Micro-training factor}

Factor I explains 47.63 percent of total variance. This includes TQ1, TQ2, TQ3, TQ4 and TQ5. This factor has also significant factor loadings on these variables which are formed this major cluster. So this factor has provided a basis for conceptualization of dimension which can be called as "Micro training factor." 
Factor II: Micro-Savings factor

Factor II explains 24.07 percent of total variance. This includes SQ1, SQ2, SQ3, and SQ4. This factor has also significant factor loading on these variables which formed second important cluster with respect to the variation. So this factor provided a basis for conceptualization of dimension which can be called as "Micro saving factor."

\section{Factor III: Micro-credit factor}

Factor III explains 17.16 percent of total variance. This includes CQ1, CQ2, CQ3, CQ4 and CQ5. This factor has also significant factor loading on these variables which formed third important cluster with respect to the variation. So this factor provides a basis for conceptualization of dimension which can be called as "Micro credit factor."

Table 7: Factor wise average score

\begin{tabular}{|c|l|l|l|}
\hline $\begin{array}{l}\text { Serial } \\
\text { No: }\end{array}$ & Factor & $\begin{array}{l}\text { Factor } \\
\text { score }\end{array}$ & Rank \\
\hline I & $\begin{array}{l}\text { Micro- } \\
\text { training }\end{array}$ & 0.209 & 2 \\
\hline II & $\begin{array}{l}\text { Micro- } \\
\text { saving }\end{array}$ & 0.261 & 1 \\
\hline III & $\begin{array}{l}\text { Micro- } \\
\text { credit }\end{array}$ & 0.204 & 3 \\
\hline
\end{tabular}

Source: Survey data

Based on the factor wise average score in table 7 , the results indicated that factor II: Microsaving is the most significant issue that impedes the entrepreneurs' performance in Pilimathalawa area. This factor includes provide capital necessary to invest (SQ1),
Risk of repayment of loan (SQ2), Cover the expenditure of the business (SQ3) and Smooth irregular income (SQ4). This has reflected own savings of the entrepreneurs were best asset for the entrepreneurs. Therefore it was highly significant than the other factors.

The second most important factor is Micro-training. This factor includes Knowledge of financial literacy (TQ1), Management skills (TQ2), Operational skills (TQ3), Technological skills (TQ4) and Knowledge of leadership (TQ5). These factors have been found working as improve the business knowledge of the entrepreneur.

Micro-credit factor includes Physical assets of the business (CQ 1, Machines/ tools/ equipment), Operational facility (CQ2), Number of products (CQ3), Number of buyers (CQ4) and Business volume (CQ5) and it was third significant factor.

Based on the results, cumulative variance of three factors is $88.8 \%$. It observed that the micro-saving has higher significant factor for micro entrepreneurs in Pilimathalawa area in Sri Lanka.

\section{FINDINGS}

The multiple regressions and correlation analysis were done in this study for measuring the relationship between independent and dependent variable. The results indicated that the positive 
relationship between micro-credit service and entrepreneurs' performance was observed and the micro-credits have significantly influence on the entrepreneurs' performance. The micro-saving have positively correlated and significantly influence on the entrepreneurs' performance and the micro-trainings also have positively influence on the entrepreneurs' performance of this study. The results were supported with the prior researchers (Khin et al. 2017, Syed Hussain Haider et.al 2018, and Kingsley Bernard et al 2018).

Finally the factor analysis was done in this for finding the most important factor of microfinance services on the entrepreneurs' performance. The results found that micro-savings has most important factor of microfinance services factor. Respondents have shown savings are performed as an asset and helped in increase entrepreneurs' performance without any other interventions than the other two services. The result was supported with the research done by Prasansha Kumari (2014). Further the study identified that the derived hypotheses were accepted. Finally the study found that the microfinance services highly significant to the micro entrepreneurs in Pilimathalawa Area in Sri Lanka.

\section{CONCLUSION}

This study critically examined effect of microfinance services on entrepreneurs' performance in Pilimathalawa area, who are utilizing microfinance services from the microfinance institutions. Microfinance is the widely used throughout the Sri Lanka for many decades as tool to develop the entrepreneurs. This study carried out by collecting data from 100 beneficiaries who have obtained microfinance facilities from the selected institution (Samurdhi Bank) in Pilimathalawa area. Researchers employed correlation, multiple regression and factor analysis to examine and present the collected information.

Findings of the study showed that microfinance services have significantly impact on the performance of micro entrepreneurs in Pilimathalawa area. The study concludes that microfinance credit service and saving service have more significant effect on the performance of entrepreneurs. The study also concludes that training service offered by micro finance institutions have significantly improve the skills and knowledge of entrepreneurs which transferred to their business purposes. And also the results of factor analysis found that micro-savings service ranking in the microfinance factor which mostly effect on the entrepreneurs' performance. Respondents have shown savings are performed as an asset and 
helped in increase entrepreneurs' performance without any other interventions than the other two services.

\section{RECOMMENDATIONS}

Recommendations are absolutely paramount in any research. In this research, based on the analysis of role of microfinance services in entrepreneurs' performance, the following recommendations are made. The following recommendations would be forwarded for research study based on the findings of this research study for further development of their practices.

$>$ Knowledge and information should provide to beneficiaries regarding how to use the micro-credit, microsavings and micro-training services effectively for achieving their objectives and should help to progress their business.

\section{Normally microfinance} institution deal with low income people. However rich people should attract for microfinance only for serving credit facilities. But micro finance institutions can accept their savings and also can provide training and other financial services also.

The microfinance institutions need to conduct a training assessment in order to establish what kind of training is suitable for entrepreneurs. They should train them on proper finance and business management practices to professionally manage their businesses.

$>$ Microfinance institutions should train micro entrepreneurs on proper business practices to avoid business failures.

There should have a regulatory framework for supervising and monitoring micro financial institution and provide better service for their beneficiaries.

\section{DIRECTIONS FOR FURTHER STUDIES}

This research provides direction for further research. Here, the researchers have considered about the micro entrepreneurs who are utilizing microfinance services from Samurdhi Bank. Because in Pilimathalwa area Samurdhi Bank was only micro finance institution which provides all three microcredit service, micro-savings service and micro-training service for their beneficiaries. But in future, any researcher who is interested in the field can undertake a research regarding any other one or more micro finance institutions also. In addition, this study focused on particular area, but in the future this study can be carried out in District wise, Province wise and Island wise. In this study the researchers was selected only 100 entrepreneurs 
among the number of entrepreneurs who were utilized micro finance services from Samurdhi Bank. In future, this study can be carried out with large number of entrepreneurs and as well large number of sample.

\section{REFERENCES}

Diaka, H.S., \& Asenge, E.L. (2019), Effect of microfinance Banks on the Performance of Selected Women-Owned

Enterprises in Makurdi Metropolis, Benu State, Nigeria, The International Journal of Business Management and Technology, 3(1), 39-46.

Fairoz, F. M., Hirobumi, T., \& Tanaka, Y. (2010). Entrepreneurial Orientation and Business Performance of small and medium scale Enterprises of Hambanthota District, Sri Lanka, Asian Social Science, 6(3), 34-46.

Haider, H.S., Asad, M., \& Fatima, M. (2018), Microfinance and Performance of Micro and Small Enterprises; Does training has an Impact, International Journal of Small Business and Entrepreneurship Research, 6 (4), 40-49.

Herath, A.W.M.H., Guneratne, P.H.L., \& Sanderatne
Nimal (2015), Impact of Microfinance on Women's Empowerment: A Case Study on Two Microfinance Institutions in Sri Lanka, Sri Lanka Journal of Social Sciences, 38(1), 51-61.

Khavul, S. (2010). Microfinancing: Creating opportunities for the poor? Academy of Management Perspectives 24(3), 58-72.

Kingsley Bernard, T.D. (2015), Microfinance services: Facilitating Entrepreneurial Success of Poor Women, Review of Contemporary Business Research, 4(2), 57-66.

Kingsley Bernard, T.D., Kevin Lock Teng, W.O.L., \& Khin, A.A. (2017), Influence of Microfinance Services on Entrepreneurial Success of Women in Sri Lanka, African Journal of Business Management, 11(4), 337-346.

Kinimi, L.N. (2014), The Effect of Microfinance Institutions on the Performance of Small and Medium-Sized Enterprises in the Democratic Republic of Congo, Mini-dissertation submitted in partial fulfillment of the requirements for the degree Master of Business Administration at the 
Potchefstroom Campus of the NorthWest University. $1-83$.

Kithae, P.P., Nyaga, G.Juster, and Kimani, G.J., (2013), Role of Microfinance Factors on the Sustainability of Women Managed Miro and Small Enterprises (MSEs) in Kenya, International NGO Journal, 8(4), 94-99.

Ojoolu, 2009, Impact of Microfinance on

Entrepreneurial

Development: the case of Nigeria, 536-545

Osunde C.(2012), Microfinance and entrepreneurial development in Nigeria, Jorind 10(3), 405-410.

Prasansha Kumari, J.A. (2014),

The Impact of microfinance on Small Entrepreneurship in Sri Lanka, BIOINFO Business Economics, 2(1), 06-09.

Senanayake, P.M.S., \& S.P.Premaratne, P.S. (2005). Microfinance for Accelerated Development, Sri Lanka Economic Association Annual Sessions 2005 